\title{
PROGNOSTIC VALUE OF SERUM AMYLOID A PROTEIN COMPARED WITH C-REACTIVE PROTEIN IN PATIENTS WITH INFLUENZA
}

\author{
Iliyan Todorov', Margarita Gospodinova ${ }^{1}$, Yana Bocheva ${ }^{2}$, Gergana Popcheva ${ }^{2}$ \\ ${ }^{1}$ Department of Infectious Diseases, Faculty of Medicine, Medical University of Varna \\ ${ }^{2}$ Department of General Medicine and Clinical Laboratory, Faculty of Medicine, \\ Medical University of Varna
}

\begin{abstract}
INTRODUCTION: Acute phase response represents an increase in hepatic production of the so-called acute phase proteins (APP). Until now, C-reactive protein (CRP) has routinely been measured as an indication of bacterial infections. Serum amyloid A (SAA) is a novel marker. It is a more conservative protein for viral etiology of the disease. We analyzed the dynamic changes of SAA and CRP during influenza infection and evaluated the role of SAA as a significant marker for viral infections.

MATERIALS AND METHODS: We studied 31 patients with clinically suspected and serologically proved influenza, hospitalized in the Department of Infectious Diseases at St. Marina University Hospital, Varna. Serum levels of SAA and CRP were measured on admission and $4.23 \pm 1.03$ days later by immunoturbidimetric assays, adapted on Olympus AU 400.

RESULTS: The mean serum concentrations of SAA during the acute stage were $168.92 \mathrm{mg} / \mathrm{L}$ and those of CRP were $48.08 \mathrm{mg} / \mathrm{L}$. In the group of bacterial complications, such as bronchitis, sinusitis and otitis media, the SAA levels were 5- to 9-fold greater than CRP. Analyses of the second measurement showed a tendency of serum SAA to disappear more quickly than CRP - $52.11 \mathrm{mg} / \mathrm{L}$ vs. $16.71 \mathrm{mg} / \mathrm{L}$.

CONCLUSION: SAA is more sensitive APP than CRP in viral infection settings. In cases of bacterial superinfections, serum SAA is more predominant than CRP, indicating the necessity of an antibiotic therapy. Prompt downgrading of SAA in sera correlates with auspicious prognosis could be used as an effective treatment monitoring. Scr Sci Med. 2017;50(1):15-19
\end{abstract}

Keywords: acute phase proteins, serum amyloid A, C-reactive protein, influenza, viruses, infections

Address for correspondence:

Iliyan Todorov

Department of Infectious Diseases

Faculty of Medicine

Medical University of Varna

55 Marin Drinov St

9002 Varna

e-mail:ilio_87@abv.bg

Received: January 26, 2018

Accepted: March 15, 2018

\section{INTRODUCTION}

Infectious diseases run their clinical course as result of inflammation caused by viral or bacterial infection. It leads to acute phase response (APR) from the immune system, mediated by hepatic production of more than 200 acute phase proteins (APP) (1). Measurement of some of them in the patient's sera is helpful to early diagnosis, differential diagnosis and evaluation of the effect of the initiated treatment $(2,3)$. The first described APP is C-reactive pro- 
tein (CRP) and it is routinely measured today as an indicative marker for acute bacterial infections when its serum concentrations are high (4). Novel investigations are focused on another APP named serum amyloid A protein (SAA) $(4,5)$. First, its function was not exactly clear and it was described in the literature as a protein without function (6). Years later it was found that it acts as an apolipoprotein of high-density lipoproteins (HDL), increasing in the serum up to 1000 -fold in response to inflammation. Various international studies show that SAA may be a more sensitive inflammatory marker than CRP, especially during viral infections, where CRP changes are in a narrower range $(7,8,9)$.

\section{AIM}

The aim of the study is to investigate the correlation between SAA and CRP in influenza and to assess the role of SAA as a significant marker for inflammation with viral causes. To achieve it, we evaluated SAA/CRP kinetics in non-complicated influenza cases; SAA/CRP kinetics in complicated influenza cases; correlation between SAA and CRP changes; and the possibility for SAA to be used as a marker for early effective treatment response.

Material and Methods: The prospectively studied group consisted of 31 patients with influen$\mathrm{za}$, hospitalized in the Department of Infectious Diseases at the St. Marina University Hospital, Varna, Bulgaria in the period December 2014 - February 2016. The patients were between 1 and 60 years old and did not suffer from any chronic diseases. They were divided into 2 subgroups: non-complicated influenza - 21 patients and complicated influenza - 10 patients. The diagnosis was proven by clinical/epidemiological observations and serological analysis for anti-influenza IgM/IgG in the serum sample on the day of admission. For measuring the serum levels of SAA and CRP immunoturbidimetric assays, adapted on Olympus AU 400 were used. Reference ranges for SAA were up to $10 \mathrm{mg} / \mathrm{L}$ and for CRP - up to $5 \mathrm{mg} / \mathrm{L}$ based on the aforementioned techniques.

\section{RESULTS}

Our study included 31 patients with influenza. The sex and age distribution are shown on Fig. 1 and Fig. 2, respectively.

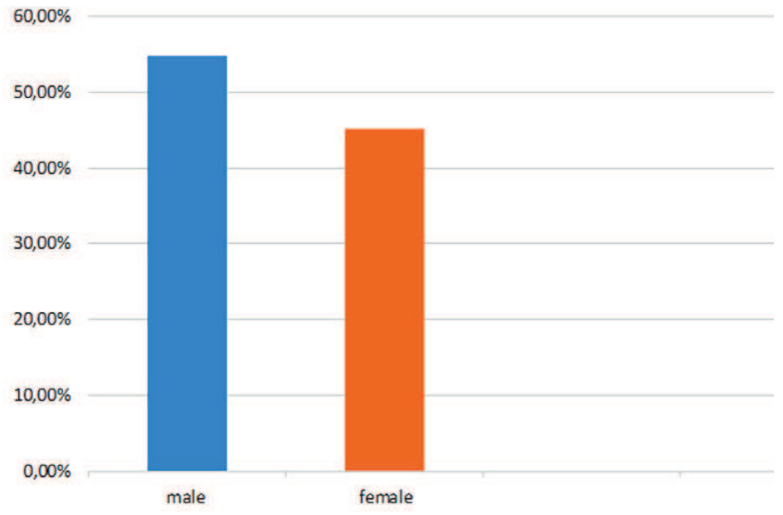

Fig. 1. Sex distribution of the patients - 17 (54.84\%) men and $14(45.16 \%)$ women

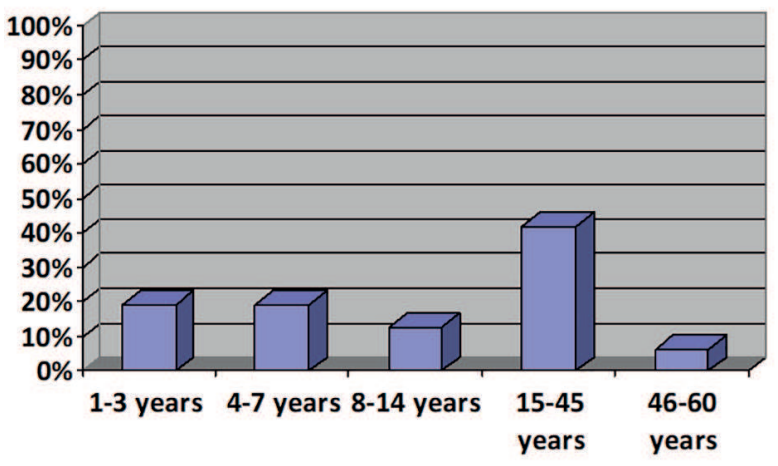

Fig. 2. Age distribution of the patients

Twenty-one of them became acutely ill 1 day before hospitalization, 7 - 2 days before hospitalization and in just 3 patients the diagnosis was suspected 3 days prior to hospitalization. All patients had clinical signs and symptoms highly suspicious of seasonal influenza: acute onset of fever more than $38.6^{\circ} \mathrm{C}$, severe myalgias, fatigue and weakness, frontal and retro-orbital headache, dry cough.

During the period of hospitalization, 7 patients had complications of acute bronchitis, 1 - pneumonia, 1 - sinusitis, and 1 - otitis media (Tab. 1).

All 31 patients were analyzed twice for SAA and CRP - first on the day of admission and second $4.23 \pm 1.03$ days later.

On the day of admission higher than normal SAA was detected in 28 patients $(90.32 \%)$ while in 3 $(9.68 \%)$ of them it was within the reference range. In regard to CRP - it was increased in 24 cases $(77.42 \%)$ and normal in 7 (22.58\%). The mean SAA concentra- 
Iliyan Todorov, Margarita Gospodinova, Yana Bocheva et al.

Table 1. Patients and illness characteristics

\begin{tabular}{|c|c|c|c|c|c|}
\hline Illness characteristic & 1-3 years & 4-7 years & 8-14 years & $15-45$ years & 46-60 years \\
\hline \multicolumn{6}{|l|}{ Disease onset: } \\
\hline $\begin{array}{l}\diamond 1 \text { day before admission / } \\
11-35.48 \% \text { of the patients/ }\end{array}$ & 6 & 2 & 1 & 2 & 0 \\
\hline $\begin{array}{l}\diamond 2 \text { days before admission } \\
\text { /7-22.58\% of the patients/ }\end{array}$ & 0 & 2 & 1 & 4 & 0 \\
\hline $\begin{array}{l}3 \text { day before admission } \\
\text { /13-41.94\% of the patients/ }\end{array}$ & 0 & 2 & 2 & 7 & 2 \\
\hline \multicolumn{6}{|l|}{$\begin{array}{l}\text { Pre-hospital care: } \\
\quad \diamond \text { Antibiotics }\end{array}$} \\
\hline$\diamond$ Antiviral & & & & & \\
\hline $\begin{array}{l}\diamond \text { Antipyretics } \\
\diamond \text { Vitamins }\end{array}$ & & $\begin{array}{l}3 \\
2\end{array}$ & $\begin{array}{l}2 \\
1\end{array}$ & $\begin{array}{l}9 \\
5\end{array}$ & 2 \\
\hline Mean temperature on admission, ${ }^{\circ} \mathrm{C}$ & $39.1 \pm 1.0$ & $38.9 \pm 1.1$ & $38.7 \pm 0.9$ & $38.7 \pm 1.0$ & $39.2 \pm 0.9$ \\
\hline Disease duration in days & $4.66 \pm 1.0$ & $4.5 \pm 0.95$ & $4.5 \pm 0.96$ & $3.92 \pm 1.01$ & $3.5 \pm 0.1$ \\
\hline \multicolumn{6}{|l|}{ Complications: } \\
\hline$\diamond$ Acute bronchitis & 1 & 3 & 1 & 2 & \\
\hline$\diamond$ Acute pneumonia & & 1 & & & \\
\hline$\diamond$ Acute otitis media & & & 1 & & \\
\hline$\diamond$ Acute sinusitis & & & 1 & & \\
\hline \multicolumn{6}{|l|}{ Diagnosis: } \\
\hline$\diamond$ Influenza A & 1 & 2 & & 3 & \\
\hline$\diamond$ Influenza B & & & & & 1 \\
\hline$\diamond$ Non-identified influenza & 5 & 4 & 4 & 10 & 1 \\
\hline
\end{tabular}

tion was significantly higher than CRP: $168.92 \mathrm{mg} / \mathrm{L}$ versus $48.08 \mathrm{mg} / \mathrm{L}$.

In the subgroup of non-complicated influenza, the mean value of SAA was $157.55 \mathrm{mg} / \mathrm{L}$, with the highest concentration of $655.9 \mathrm{mg} / \mathrm{L}$ measured in one 46-year-old male patient. As it was mentioned above 11 patients became ill just 1 day before hospitalization. Their mean level of SAA was $55.4 \mathrm{mg} / \mathrm{L}$.

The serum levels of CRP in the same subgroup showed a mean value of $53.16 \mathrm{mg} / \mathrm{L}$, which was 8.56 $\mathrm{mg} / \mathrm{L}$ for those who became ill 1 day prior to hospitalization (Fig. 3).

The SAA/CRP mean ranges in the complicated cases of influenza were $202.0 \mathrm{mg} / \mathrm{L}$ versus 37.30 $\mathrm{mg} / \mathrm{L}$. Extremely high SAA was observed in the patients with acute bronchitis $(1041.0 \mathrm{mg} / \mathrm{L})$, acute sinusitis $(390.4 \mathrm{mg} / \mathrm{L})$, and acute otitis media $(281.3$ $\mathrm{mg} / \mathrm{L}$ ). In these cases, the serum levels of CRP were $166.98,72.51$, and $8.22 \mathrm{mg} / \mathrm{L}$, respectively.
The mean value of SAA for all 31 patients from the second sample was $52.11 \mathrm{mg} / \mathrm{L}$ versus $16.71 \mathrm{mg} / \mathrm{L}$ for CRP. SAA was normal in 22 patients (70.97\%) while $9(29.03 \%)$ sera probes reacted with increased SAA up to $982.7 \mathrm{mg} / \mathrm{L}$. CRP was normal in 21 (67.74\%) and abnormal in 10 (32.26\%) patients.

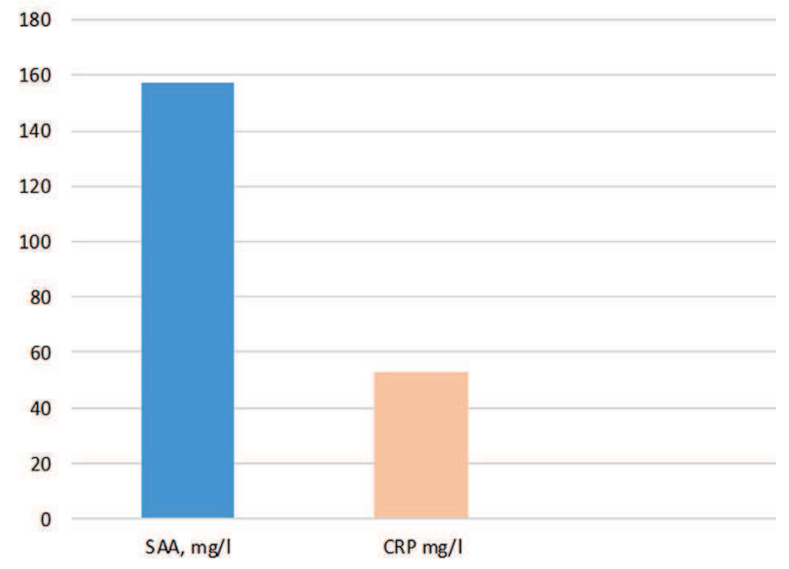

Fig. 3. Mean SAA/CRP value from the first serum sample in the group of non-complicated cases 
In the subgroup of non-complicated cases mean SAA/CRP levels from the second serum sample were 27.96/15.02 mg/L. Normal value of SAA was regis-

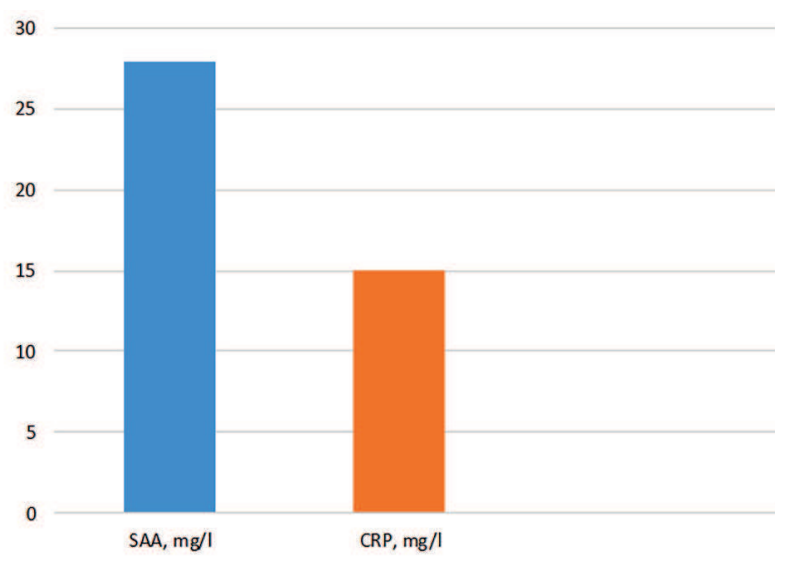

Fig. 4. Mean SAA/CRP value from the second serum sample in the group of non-complicated cases

tered in all of the patients with a 3-day history of illness while CRP was normal just in 5 of them (Fig. 4).

In the complicated influenza subgroup, the second sample showed mean SAA value of $102.0 \mathrm{mg} / \mathrm{L}$ and mean CRP value of $100.16 \mathrm{mg} / \mathrm{L}$.

\section{DISCUSSION}

Human acute phase SAA is a-globulin, which belongs to the apolipoprotein family (10). Its functions are still not fully understood (11). Some of the most important ones are inhibition of antibody production, mediation of fever and platelet aggregation, together with induction of chemotaxis and some proteases $(12,13,14,15)$.

Increased serum SAA concentrations have been reported in various viral infections, such as influenza, rhinovirus, measles, chickenpox, hand-foot-andmouth disease, etc. $(16,17)$. Such propositions correlate with the results of our study, where $90.32 \%$ of the patients with influenza showed significant increase of SAA concentration in the acute phase of the disease with a mean 16-fold increase over the reference range. Different studies introduce data about more conservative changes in CRP concentrations in the course of viral infections and it is commonly increased in bacterial cases $(1,4,18)$. In our patients the mean CRP value from the first serum samples is $48.08 \mathrm{mg} / \mathrm{L}$ in contrast to the mean value of SAA - $168.92 \mathrm{mg} / \mathrm{L}$. This statement confirms important current data about measuring SAA as a sensitive marker for inflammation with viral causes in situations when CRP is also reactive (2).

Serum amyloid A is the earliest APP which appears in the serum 3-6 hours after acute inflammations. C-reactive protein kinetics parallel that but is less pronounced $(4,18)$. The same changes are observed in our study - mean value of SAA in the patients with a 1-day illness history is $55.4 \mathrm{mg} / \mathrm{L}$ for SAA versus $8.56 \mathrm{mg} / \mathrm{L}$ for CRP.

According to Nakayama et al., the maximum value of SAA is observed 48 hours after the onset of the inflammation, returning to baseline 4-5 days later (19). CRP changes are the same but more conservative. Our results confirm these data - the mean value of SAA is 3 times below the initial $(52.11 \mathrm{mg} / \mathrm{L})$ while CRP is decreased to a lesser extent $(16.71 \mathrm{mg} / \mathrm{L})$. So, SAA is a significant marker for early clinical improvement. Patients whose inflammatory markers are still abnormal and have not had full recovery require high medical attention and therapy revision.

Significant difference is observed in the initial range of SAA/CRP in non-complicated and complicated subgroups. In the first subgroup mean SAA is $157.55 \mathrm{mg} / \mathrm{L}$, and in the second $-202.0 \mathrm{mg} / \mathrm{L}$, while CRP changes are roughly similar $(53.16 / 37.30 \mathrm{mg} / \mathrm{L})$. It means that extremely high SAA $(>200 \mathrm{mg} / \mathrm{L})$ indicates possible bacterial complication and calls for empiric antibiotic treatment. The same results may be seen in the study of Chambers et al., who suggest that SAA is of value in monitoring the severity of the inflammation and the recovery process in viral infections (20). The second samples in both subgroups show a significant decrease in the evaluated markers, but in the group of complicated forms, the results are the opposite - decrease of SAA and increase of CRP. In this context, SAA may be an early marker for effective treatment monitoring.

\section{CONCLUSION}

In viral infections SAA is a more sensitive APP than CRP. In the cases of bacterial superinfections, serum SAA is higher than CRP, indicating a necessity of antibiotic therapy. Prompt downgrading of SAA in sera correlates with auspicious prognosis and could be used as an effective treatment monitoring. 
Iliyan Todorov, Margarita Gospodinova, Yana Bocheva et al.

\section{Conflict of interest}

All the authors declare that they have no conflict of interest related to the work described in this report.

\section{REFERENCES}

1. Cray C, Zaias J, Altman NH. Acute phase response in animals: a review. Comp Med. 2009;59(6):517-26.

2. Malle E, De Beer FC. Human serum amyloid A (SAA) protein: a prominent acute-phase reactant for clinical practice. Eur J Clin Invest. 1996; 26(6):427-35.

3. Tamamoto T, Ohno K, Takahashi M, Nakashima K, Fujino Y, Tsujimoto H. Serum amyloid A as a prognostic marker in cats with various diseases. Journal of Veterinary Diagnostic Investigation. 2013; 25(3):428-32. doi: 10.1177/1040638713486112.

4. Abernethy JT, Avery OT. The occurrence during acute infections of a protein not normally present in the blood. I. Distribution of the reactive protein in patients' sera and the effect of calicum on the flocculation reaction with C polysaccaride of Pneumococcus. J Exp Med. 1941; 73(2):173-82.

5. Gabay C, Kushner I. Acute-phase proteins and other systemic responses to inflammation. $\mathrm{N}$ Engl J Med. 1999; 340(6): 448-54. doi: 10.1056/ NEJM199902113400607.

6. Bjorkman L. The role of serum amyloid A in inflammatory disease - proinflamatory mediator or inert biomarker?, Doctoral Thesis. Sweden. 2010; ISBN: 978-91-628-8050-7.

7. Chaplin D. Overview of the immune response. J Allergy Clin Immunology. 2010; 125(2 Suppl 2):S323. doi: 10.1016/j.jaci.2009.12.980.

8. Cicarelli D, Vieira J, Bensenor P. Comparison of Creactive protein and serum amyloid A protein in septic shock patients. Mediators of Inflammation. 2008;2008:631414. doi: 10.1155/2008/631414.

9. Uhlar C, Whitehead A. Serum amyloid A, the major vertebrate acute-phase reactant. Eur J Biochem. 2001; 265(2):501-23.

10. Rienhoff HY Jr, Huang JH, Li XX, Liao WS. Molecular and cellular biology of serum amyloid A. Mol Biol Med. 1990; 7(3):287-98.

11. Tamamoto T, Ohno K, Ohmi A, Seki I, Tsujimoto $\mathrm{H}$. Timecourse monitoring of serum amyloid A in a cat with pancreatitis. Vet Clin Pathol. 2009; 38(1):83-6. doi: 10.1111/j.1939-165X.2008.00082.x.
12. Badolato W, Wang JM, Murphy WJ, Lloyd AR, Michiel DF, Bausserman LL, et al. Serum amyloid A is a chemoattractant: induction migration, adhesion, and tissue infiltration of monocytes and polymorphonuclear leukocytes. J Exp Med. 1994; 180(1):203-9.

13. Lannergard A, Larsson A, Kragsbjrerg P, Friman G. Correlations between serum amyloid A protein and C-reactive protein in infectious diseases. Scand J Clin Lab Invest. 2003; 63(4):267-72.

14. Lannergard A. Serum amyloid A protein (SAA) in healthy and infected people. Acta Universitatis Upsaliensis. Sweden. 2005; ISBN: 978-91-628-8050-7.

15. Patel H, Fellowes R, Coade S, Woo P. Human serum amyloid A has cytokine - like properties. Scand J Immunol. 1998; 48(4):410-8.

16. Falsey AR, Walsh EE, Francis CW, Looney RJ, Kolassa JE, Hall WJ, et al. Response of C-Reactive Protein and Serum Amyloid A to Influenza A Infection in Older Adults. The Journal of Infectious Diseases. 2001; 183(7):995-9. doi: 10.1086/319275

17. Stenfeldt, Heegaard P, Stockmarr A, Tjørnehøj K, Belsham G. Analysis of acute phase responses of serum amyloid $\mathrm{A}$, haptoglobin and type 1 interferon in cattle experimentally infected by food-andmouth disease virus serotype O. Vet Res. 2011; 42:66. doi: 10.1186/1297-9716-42-66.

18. Jensen $L$, Whitehead A. Regulation of serum amyloid A protein expression during the acute-phase response. Biochem J. 1998; 334(Pt 3):489-503.

19. Nakayama $T$, Sonoda $S$, Urano $T$, Yamada $T$, Okada M. Monitoring both serum amyloid A protein and C-reactive protein as inflammatory markers in infectious diseases. Clin Chem. 1993; 39(2):293-7.

20. Chambers R, Hutton C, Dieppe P, Whicher J. Comparative study of $C$ reactive protein and serum amyloid A protein in experimental inflammation. Annals of the Rheumatic Diseases. 1991; 50(10):677-9. 